\title{
Land Cover Change in a Freshwater Swamp Forest Landscape: Implications for Biodiversity Conservation
}

\author{
Nwabueze I. Igu ${ }^{*} \mathbb{D}$, Joseph 0. Duluora² \\ ${ }^{1}$ Department of Geography and Meteorology, Nnamdi Azikiwe University, Awka, Nigeria \\ ${ }^{2}$ Department of Environmental Management, Nnamdi Azikiwe University, Awka, Nigeria \\ Email: ${ }^{\star}$ wabuezeigu@gmail.com
}

How to cite this paper: Igu, N.I. andDuluora, J.O. (2019) Land Cover Change in a Freshwater Swamp Forest Landscape: Implications for Biodiversity Conservation. Journal of Environmental Protection, 10, 1578-1590.

https://doi.org/10.4236/jep.2019.1012094

Received: September 30, 2019

Accepted: December 10, 2019

Published: December 13, 2019

Copyright $\odot 2019$ by author(s) and Scientific Research Publishing Inc. This work is licensed under the Creative Commons Attribution International License (CC BY 4.0).

http://creativecommons.org/licenses/by/4.0/

\begin{abstract}
Forest landscapes are under much pressure globally due to changes in land use and their biodiversity and services are threatened at increasing magnitude especially in the tropics. Biodiversity and ample forest cover still remain in freshwater forest landscapes in the Niger basin of Nigeria, but are declining at astronomical scales across the region. To better understand the changes and modifications going on in the ecosystem at the landscape level, a thirty-year study (1987-2017) was conducted using remotely sensed Landsat imageries. These were processed and used to verify the dynamics in land cover changes and their major drivers. Land use change across the region reduced the forest extent and forest cover (up to 50.2 percent) of the natural ecosystems which served as the habitats for the indigenous species. Sparse vegetation and bare soil/farmlands increased over the study period and were seen as the major indices for modifications and forest loss in the area. Since land use indices such as agricultural activities were seen as one of the major factors of land cover change, sustainable forest use and management practices that accommodate agricultural practices were advocated. While the forest cover and ultimately their biodiversity and conservation prospects reduced following forest loss in the region, efforts should be targeted at conserving the pockets of vegetation seen in the sparsely vegetated zones and also maximize the potentials that the biodiversity in the agro-forested locations offers.
\end{abstract}

\section{Keywords}

Biodiversity, Carbon, Climate Change, Forest Loss, Land Use Change, Modification 


\section{Introduction}

Tropical forest ecosystems are widely reckoned epicentres of biodiversity [1] and host to at least two-thirds of the earth's terrestrial biodiversity [2]. They are very productive ecosystems that have consistently produced sufficient above ground net primary productivity (NPP) and very vital for global carbon storage and sequestration [3] [4]. It has remained a source of sustenance and income for forest communities across the tropics and is equally a source of revenue at local, regional and national levels. Such revenues include (but not limited to) derivations from the sale of timber for which loggings from the tropics contribute as much as up to one eight globally [5], income from the sale or lease of land and also other profits from the sale of other non-timber forest products such as fruits, medicine/herbs and game. On the other hand, tropical forest ecosystems equally act as or provide shelter and cultural basis (services) for most of the remaining hunter-gatherer populations (such as the Baka of central Africa) [1] and play a very active role in maintaining global biogeochemical processes [6].

Although tropical forest ecosystems are very beneficial and continue to provide very vital ecosystem services, they are lost at unprecedented rates. The rate of loss encountered just last century was so much that estimated 350 million hectares were lost to deforestation, while 500 million hectares have been degraded [7]. Such losses have continued in most locations because the bulk of fuel consumed is mainly wood fuel that is sourced from their forests. Such increased dependence on the forests as sources of sustenance and livelihood across Africa as in other tropical landscapes [8] [9] has made forest loss and forest degradation to continually be on the increase in most areas. Though such losses affect the carbon and nitrogen cycling of the ecosystem [10] and ultimately, its ecosystem functioning at local scales [11] [12], the trend of loss does not seem to be abated in most landscapes yet. Consequently, ecosystem services decline much faster and land uses are then changed to accommodate the dynamics experienced across the forest landscapes.

Across the globe, available land is becoming scarce and is continually subjected to modifications and changes in land use. Extensions of crop and pastoral land into natural ecosystems contribute to this bulk of land use changes experienced in many landscapes [13]. While it remains true and glaring that land is indeed becoming more scarce and will likely imply that more land should be allocated to land uses such as agriculture, it should be done with efficiency at sight since land use changes are major drivers and contributors to environmental changes [13] [14]. Across the Niger basin, a host of factors have continually led to the changes in the land use and cover of its forest landscapes and ecosystems without much documentation. Understanding how these changes affect ecosystems is vital steps that will help to tackle conservation issues that could endanger ecosystem viability and continuity. This study is aimed at understanding the pattern of land use/cover change and possible biodiversity conservation measures that may be adopted for the ecosystem and region. Such insights will help to 
proffer solutions to ecological issues that are becoming grave concerns across most parts of the tropics.

\section{Materials and Methods}

\subsection{Study Region}

The area is a vast sedimentary basin that is generally low-lying and found in the lower reaches of the Niger (Figure 1). It is characterized by annual flooding and accumulation of mineral-rich sediments. The zone is characterized by a tropical climate with a long rainy season that normally lasts from March to October, and shorter dry months, mainly experienced between November and February. Relative humidity in the zone rarely dips below $60 \%$ and experiences a flooding regime normally experienced towards the end of the rainy season. It is dominantly a freshwater swamp forest zone that is either seasonally or permanently flooded. Land use in the region is determined by whether the location is marshy or well drained. Agricultural activities dominate the drained landscapes, while fishing
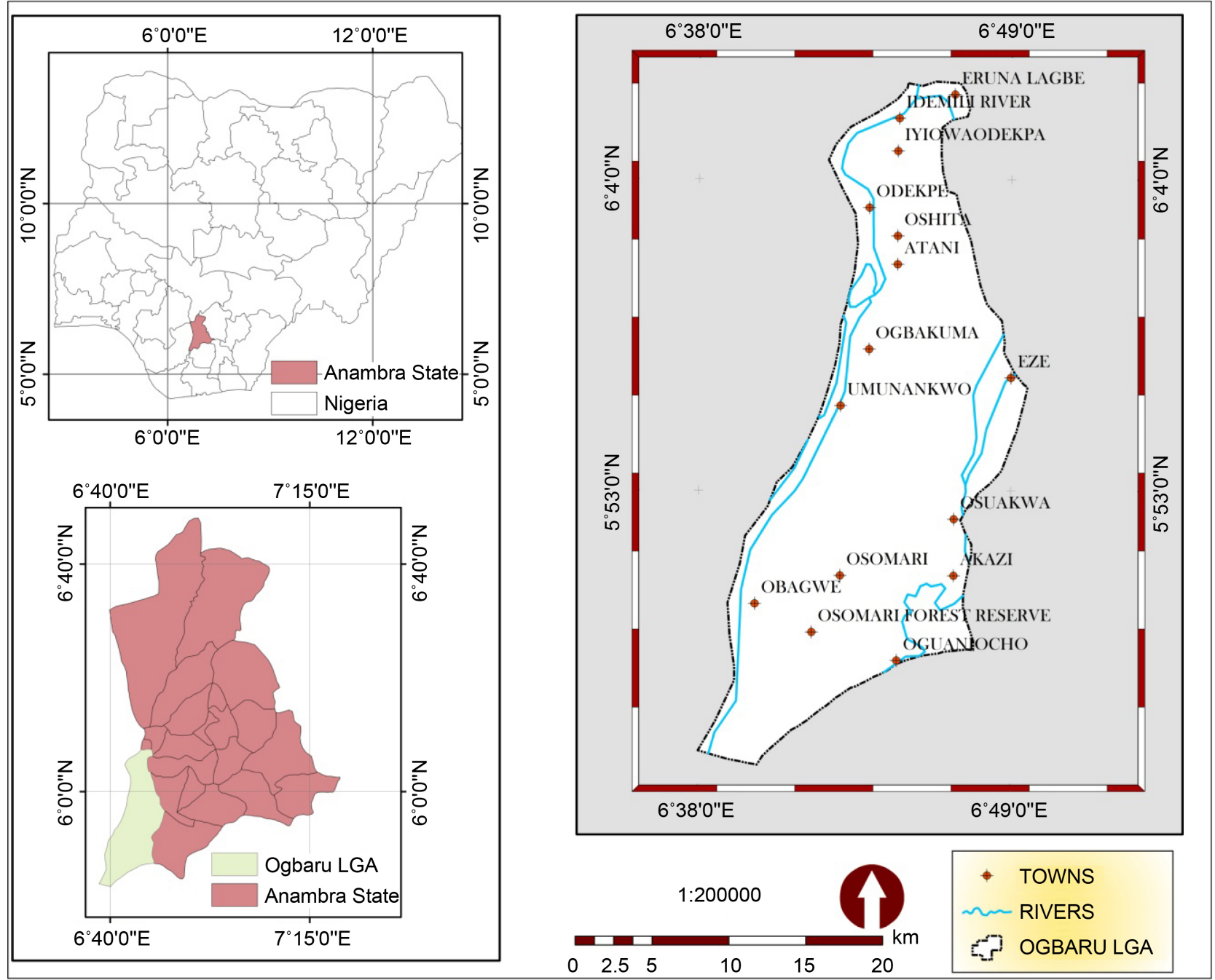

Figure 1. Map of the study area with Nigerian map inset. 
activities are mainly practiced in the swampy or marshy zones. The alluvial soils found in the region are both fertile and supports continuous cropping; hence agricultural activities are prominent features of the region. Economic activities in the zone are mainly agro-based as majority of the people are either farmers or are engaged in agro-based businesses. Fishing activities too are prominent features of the zone especially because the zone has much freshwater rivers and lakes with ample amount of fishes being harvested from them for a greater part of each year. Majority of the populace is from the Igbo tribe and are the indigenes of the land. Others are mainly from other parts of Anambra state and south eastern Nigeria generally. People from other parts of Nigeria, mainly from Delta state are equally found among them and known to transact business with them as the two locations are only separated by the river Niger.

\subsection{Data Collection}

The data used were geometrically rectified satellite imagery acquired from Global Land Cover Facilities (GLCF) website. The Landsat imagery (Path 189, Row 055) used has a resolution of $30 \mathrm{~m}$ and was acquired for the year December 1987, 2002 and January 2017. Landsat TM 1987, Landsat ETM+ 2002, and Landsat OLI/TIR 2017 were used to generate false colour composite. The analyses of observed changes were done in a GIS environment (Terrset, QGIS 2.16) in order to establish the changes over time and show same on table and maps.

\subsection{Data Classification and Analysis}

A classification scheme developed after Anderson [15] was used for the classification scheme. This scheme gives a broad classification where the land use/cover was identified as a single digit as seen below: (Table 1). The definition of bare soil and farmlands in this work denotes land without scrub, sandy areas, dry grasses, farmlands and other human induced barren lands. Built-up areas denote developed areas and include buildings as well roads.

Multi-temporal medium resolution Landsat images were used to analyze the forest dynamics in Ogbaru LGA for the period of thirty years. Furthermore, the images were classified in Terrset softare environment using the Supervised Maximum Likelihood Classification (SMLC) algorithm. The images were classified into different land cover classes and in generating land cover maps for the study region. The SMLC was used to classify the area into the five major classes

Table 1. Land use/cover classification scheme.

\begin{tabular}{cc}
\hline Code & Land use/cover categories \\
\hline 1 & Bare soil and farmland \\
2 & Built up \\
3 & Forest \\
4 & Sparse vegetation \\
5 & Water body
\end{tabular}


(Table 1). Built up area consists of the commercial, residential, road and impervious features, bare soils and farmlands consists of empty waste land with no form of development and cultivated lands, the forest consists of thick clusters of vegetation cover, the sparse vegetation includes the grasslands, shrubs, green spaces, and the water body consists of rivers and streams. Training samples were collected via visual interpretation of very high resolution images (google earth) and was used for the three images.

In order to determine the rate of forest changes in the area from 1987 to 2017, the area of coverage of the forest and other land cover types were extracted from the classified land cover maps and the raster images calculated thus:

$$
\text { Area }=\text { count } \times 30 \times 30 \times 10000
$$

The pixel values were first converted to square kilometre and then to hectares. The areas were calculated in hectares and the rate of the changes in percent. The results of the analysis were presented in tables and maps.

To ascertain the major drivers of the changes, a transition matrix for 1987 to 2017 was performed using the land change module in Terrset environment and the results presented in a map. A persistence analysis module was further done in Terrset environment to show the areas of no changes, gains and losses within the forest region.

\section{Results and Discussion}

\subsection{Rate of Forest Changes from 1987 to 2017}

The forest area under study experienced changes in its area from 1987 to 2017 (Figures 2-4). As at 1987 forest covered 15.95\%, bare soil and farmland had the highest area coverage of $55.58 \%$ and sparse vegetation had the lowest area coverage of $7.03 \%$. By 2002, the vegetal cover (forest cover and sparse vegetation: $44.17 \%$ and $30.13 \%$, respectively) increased noticeably (Figure 3 ), while bare soil and farmland, and water body areas decreased at $1.09 \%$ and $4.54 \%$, respectively (Figure 3). The built up area increased up to $20.06 \%$.

There were further decrease in forest cover $(21.09 \%)$ and a rise in the area covered by regenerating sparse vegetation (up to $36.5 \%$ ). Furthermore, the bare soil and farmlands equally increased (36.01\%), while the built-up areas and water body zones reduced by $3.36 \%$ and $2.39 \%$, respectively. In summary, a total $50.12 \%$ loss in forest cover was experienced between 1987 and 2017, 59.46\% gain in sparse vegetation, $18.49 \%$ gain in bare soil and farmlands, $12.55 \%$ loss in built-up area and a $3.63 \%$ decrease in water body extent (Table 2).

\subsection{Factors/Drivers of Forest Changes in the Region}

The forests found in the region experienced changes due to an increase in built up area, increase in the area of farmlands, and increased conversions of forest lands to bare soil (Figure 5). This meant that the sparse vegetation and forests in the area were either removed (deforested) or lost through natural processes such as flood. Since this trend persisted over the years, much of the areas covered with 


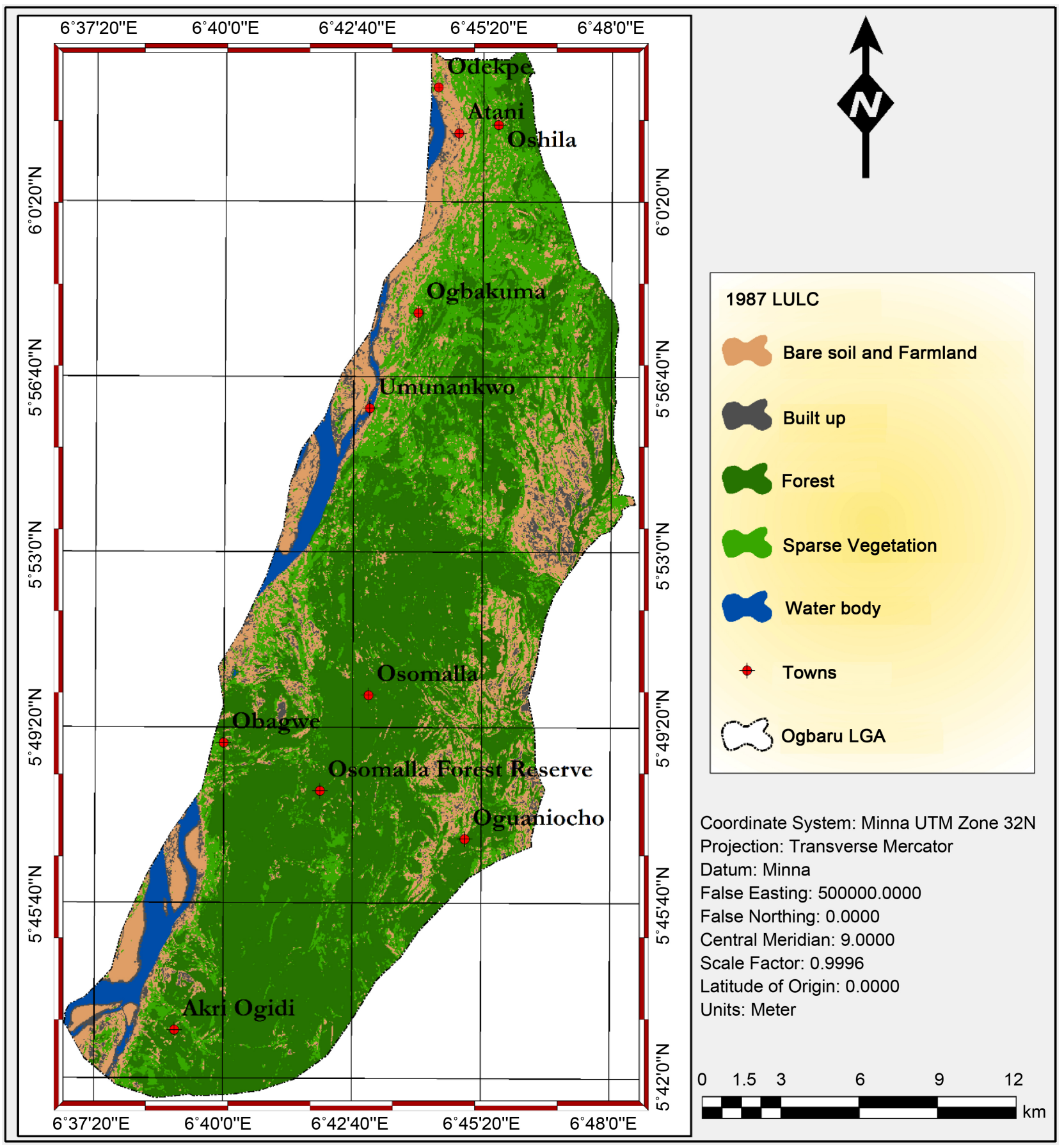

Figure 2. 1987 LULC.

vegetation were lost, very little gain was experienced and vegetation persisted or remained unchanged in some other areas (Figure 6).

\subsection{Forest Cover Dynamics and Its Prevalent Indices}

Forest cover in the region experienced unprecedented losses over the years mainly due to the factors identified: development activities (built up areas), agricultural activities (farmlands) and forest uses (deforestation). These factors are 


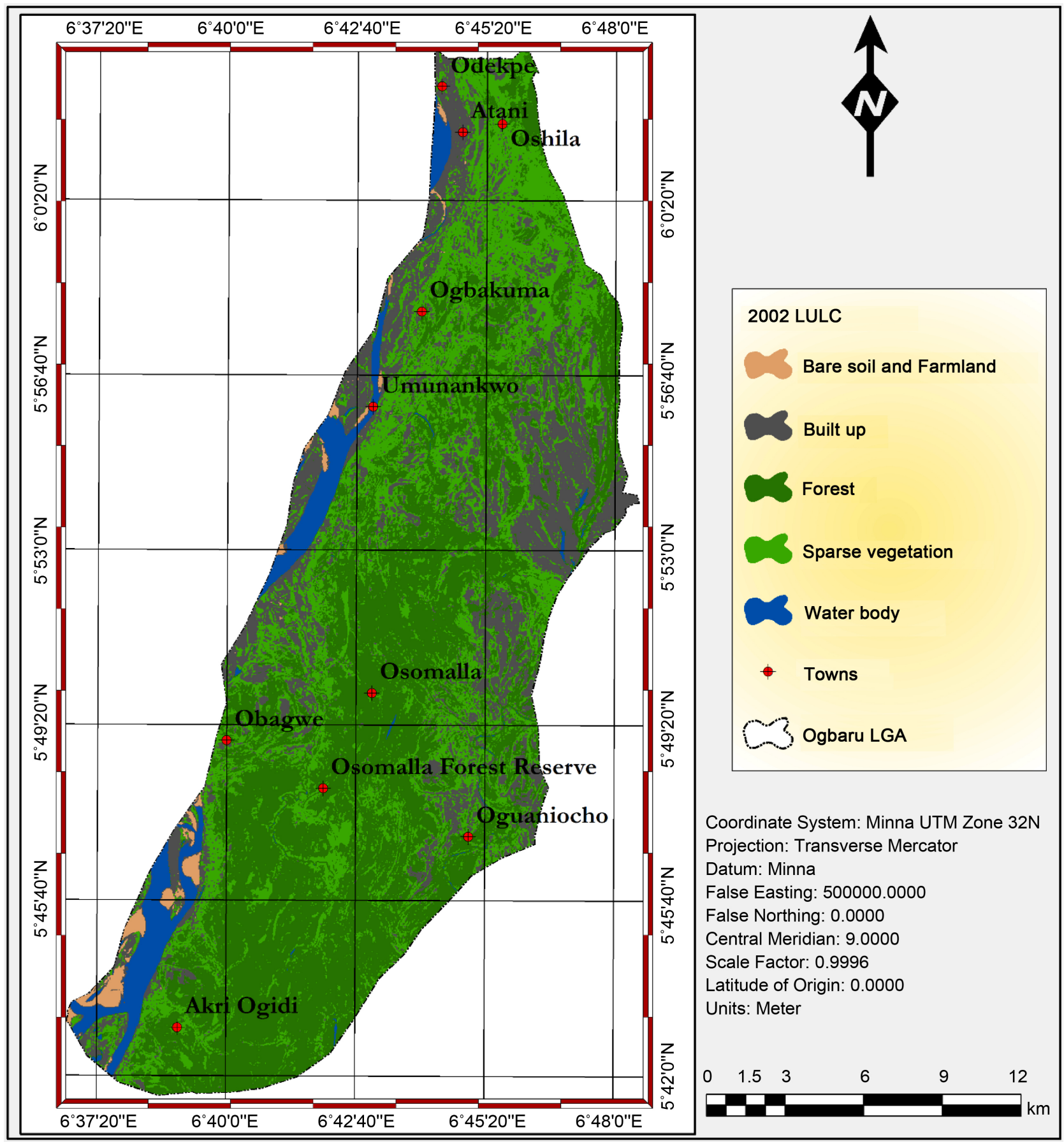

Figure 3. 2002 LULC.

among the major reasons for forest cover changes and losses experienced across many tropical landscapes [16] [17] [18], with variations in intensity across different scales. Agricultural activities (farmlands) were seen to grow over the period under review across the landscape due to factors related to population growth and the quest to meet the demands for food and income across the region. This growth in agricultural activities is both regional and global concerns as it is estimated to double by 2050 in order to meet the needs of a globally 


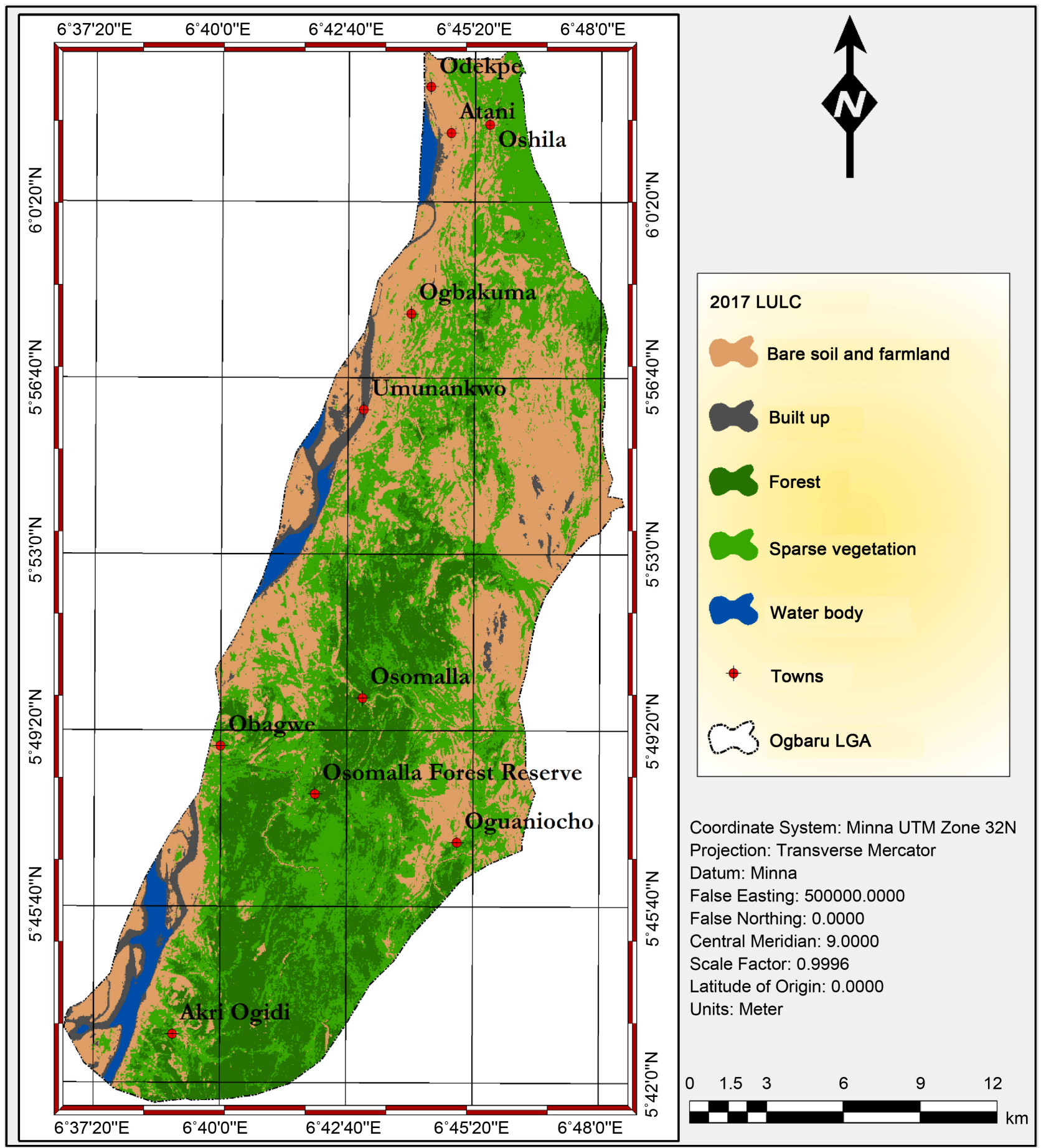

Figure 4. 2017 LULC.

increasing population [19]. With such growth in agriculture occurring across the region, much of the primary forest was lost and implied that the species diversity of the locality has become much reduced. While much of the native species were lost through agricultural intensification and expansion in the area, the biodiversity was replaced with crops and possibly tree crops such as oil palm. Such replacements account for the sparse vegetation which was seen to increase 


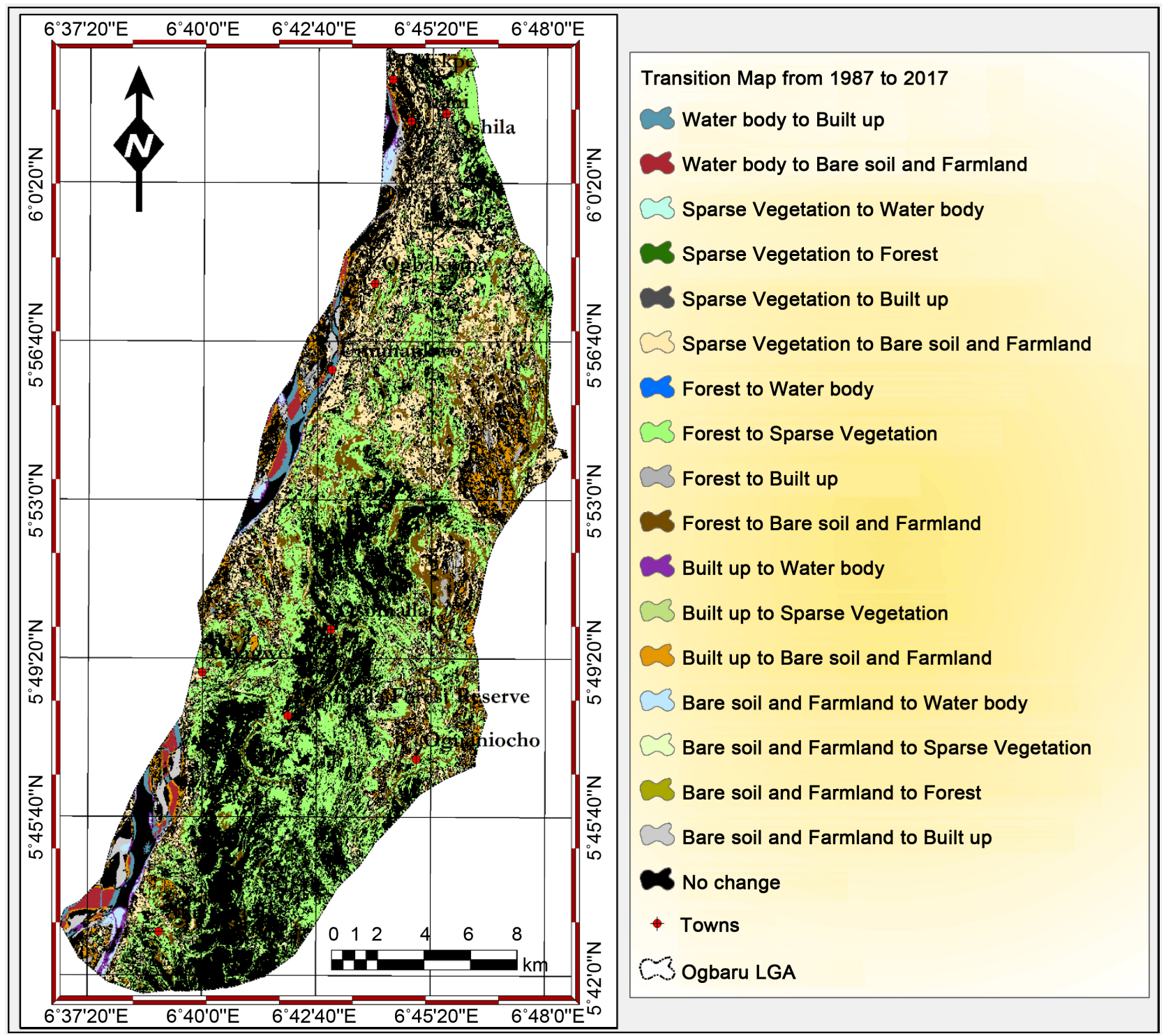

Figure 5. Drivers of forest change.

over the years and which could appear as persistent vegetation cover (as seen in Figures 2-4 and Figure 6) at a glance. Though such modified ecosystem still stores carbon (while compared to other land uses such as built up areas), however, the amount sequestered becomes much reduced compared to what native forests would normally store [20]. Furthermore, such changes in biodiversity would ultimately affect ecosystem functions as well as the livelihood of the people following reductions in ecosystem service provisions in the area.

While forest loss was seen to escalate across the region, the rate at which the forests were regained was quite poor (Figure 6). With this, even the zones where forests were seen to have persisted (mainly due to inaccessibility) cannot be totally guaranteed of continuous persistence except concerted efforts are taken to regulate the aforementioned forcings of forest loss in the region. Such strides can only be taken in the right direction if guidelines and policies on 


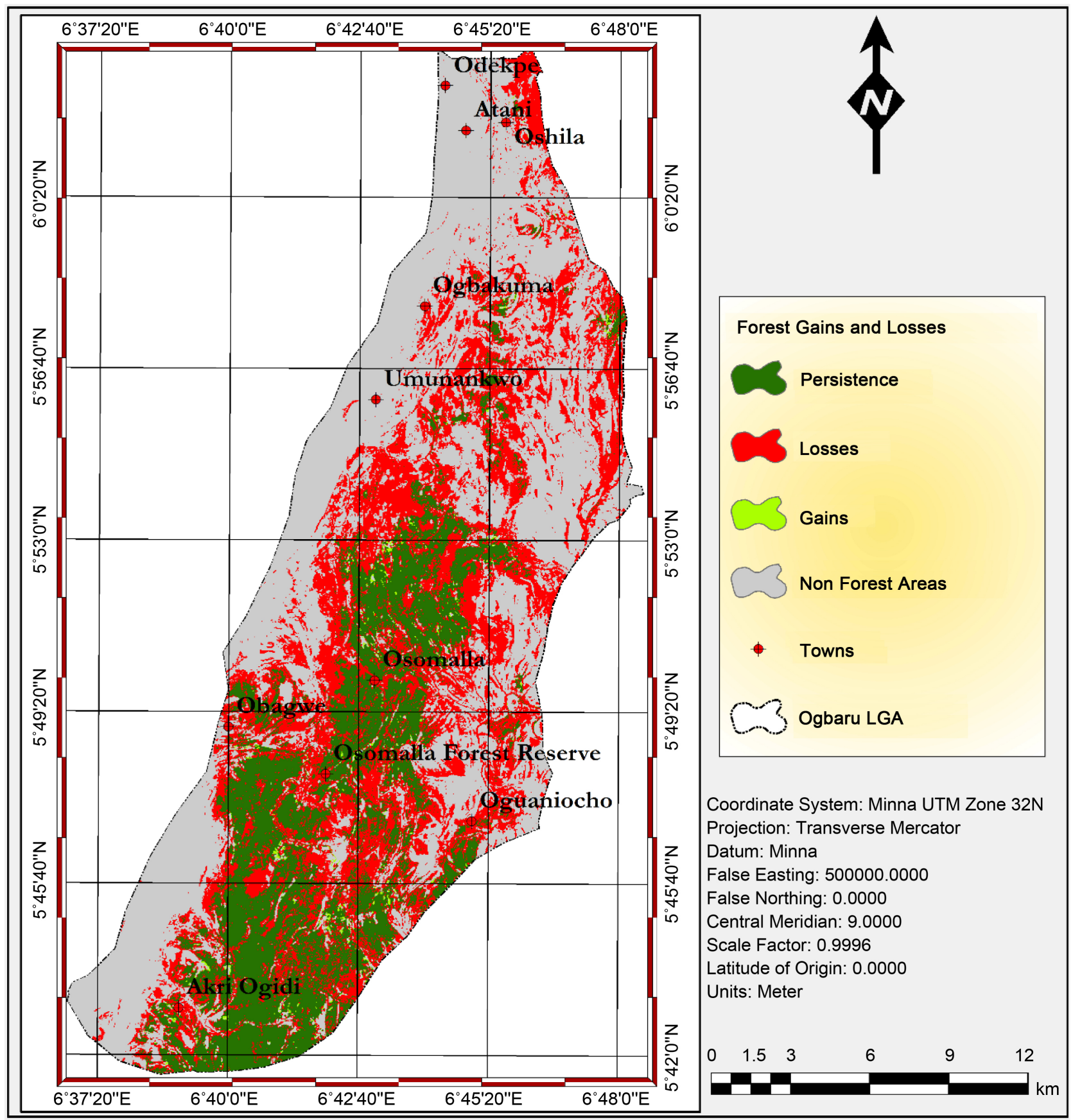

Figure 6. Forest gains and losses.

Table 2. Rate of forest changes in the area from 1987 to 2017.

\begin{tabular}{|c|c|c|c|c|c|c|c|c|}
\hline \multirow{2}{*}{$S / N$} & \multirow{2}{*}{ LULC Classes } & \multirow{2}{*}{$\begin{array}{c}1987 \\
\text { Hectares }\end{array}$} & \multicolumn{3}{|c|}{2002} & \multicolumn{2}{|l|}{2017} & \multirow{2}{*}{ Overall Changes (\%) } \\
\hline & & & $\%$ & Hectares & $\%$ & Hectares & $\%$ & \\
\hline 1 & Forest & 207,036 & 15.95 & $1,758,915$ & 44.17 & 871,965 & 21.90 & -50.12 \\
\hline 2 & Sparse Vegetation & 91,197 & 7.03 & $1,199,799$ & 30.13 & $1,447,497$ & 36.35 & 59.46 \\
\hline 3 & Bare soil and Farmland & 721,296 & 55.58 & 43,209 & 1.09 & $1,433,745$ & 36.01 & 18.49 \\
\hline 4 & Built up & 141,093 & 10.87 & 798,912 & 20.06 & 133,605 & 3.36 & -12.55 \\
\hline 5 & Water body & 137,061 & 10.56 & 180,945 & 4.54 & 94,968 & 2.39 & -3.63 \\
\hline
\end{tabular}


sustainable forest use are designed and adhered to in the locality.

\subsection{Promoting Biodiversity Conservation and Sustainable Forest Use Initiatives}

Tropical forest ecosystems are under intense pressure from land uses (such as agricultural activities) which continually threaten the species and puts them at the risk of extinction. Since this is seen to increase in magnitude across the region, proactive steps to ensure that the ecosystem is not completely lost need to be in place. Such efforts should be targeted at reforesting degraded forests (especially with species that are suitable for such landscapes) across landscapes with the support of host communities to ensure continuity of such ambitious projects. Community involvement and participation being advocated is seen to be effective only when the people concerned are aware of forest management principles involved and are willing to adhere to the tenets guiding it. Conversely, such degraded landscapes could also engage in agroforestry initiatives and seek to utilize it maximally across the landscape. Such initiative (agroforestry) accommodates varieties of tree species on farmlands, gardens and open spaces, and so could be an avenue to equally promote and improve on the biodiversity of the region. With such scheme, community members will feel restricted in their usage of lands for agriculture. This will equally make it easier to instruct them to plant trees or allow the already existing ones in their lands to coexist alongside their crops.

On the other hand, agroforestry practices conducted in the area could equally focus on planting trees (especially tree crops) in open spaces such as in the bare land (Figure 4 and Figure 5) that constitutes much of the spaces in the area. This strategy is seen as a viable solution to sustainable agriculture in tropical landscapes and a potential channel for economic returns and ecosystem service provisions [21]. Furthermore, since most people in such environments use firewood for cooking, they could be made to rely on the agroforests and planted forest landscapes for their fuel instead of the natural forests. Such initiatives will undoubtedly promote conservation and reduce degradation in the natural forests across the region.

\section{Conclusion}

Land cover of the freshwater forest landscape under study was found to experience significant changes due to land use changes emanating from development activities (built up areas), agricultural activities (farmlands) and forest uses (deforestation). While this trend of land use change is expected following population growth and associated pressure on forest ecosystems, implementing policies that promote sustainable forest use and management were seen as veritable steps to accommodate such changes and still preserve biodiversity in the region. Designing ecosystem effective and coping mechanisms that will help forest landscapes become more resilient and able to handle the growing impacts of land use 
changes and climate change is a necessity for continuous existence of tropical ecosystems.

\section{Conflicts of Interest}

The authors declare that there were no conflicts of interest during the course of the study.

\section{References}

[1] Lewis, S.L. (2006) Tropical Forests and the Changing Earth System. Philosophical Transactions of the Royal Society B, 361, 195-210.

https://doi.org/10.1098/rstb.2005.1711

[2] Gardner, T.A., Barlow, J., Chazdon, R., Ewers, R.M., Harvey, C.A., Peres, C.A. and Sodhi, N.S. (2009) Prospects for Tropical Forest Biodiversity in a Human-Modified World. Ecology Letters, 12, 561-582. https://doi.org/10.1111/j.1461-0248.2009.01294.x

[3] Pan, Y., Birdsey, R.A., Fang, J., Houghton, R., Kauppi, P.E., Kurz, W.A., Phillips, O.L., Shvidenko, A., Lewis, S.L., Canadell, J.G., Ciais, P., Jackson, R.B., Pacala, S.W., McGuire, D., Piao, S., Rautiainen, A., Sitch, S. and Hayes, D. (2011) A Large and Persistent Carbon Sink in the World's Forests. Science, 333, 988-993. https://doi.org/10.1126/science.1201609

[4] Lewis, S.L., et al. (2013) Aboveground Biomass and Structure of 260 African Tropical Forests. Philosophical Transactions of the Royal Society B, 368, Article ID: 20120295. https://doi.org/10.1098/rstb.2012.0295

[5] Blaser, J., Sarre, A., Poore, D. and Johnson, S. (2011) Status of Tropical Forest Management 2011. IITO Technical Series, No 38. International Tropical Timber Organisation, Yokohama, Japan.

[6] Cavaleri, M.A., Reed, S.C., Smith, W.K. and Wood, T.E. (2015) Urgent Need for Warming Experiments in Tropical Forests. Global Change Biology, 21, 2111-2121. https://doi.org/10.1111/gcb.12860

[7] Lamb, D., Erskine, P.D. and Parrotta, J.A. (2005) Restoration of Degraded Tropical Forest Landscapes. Science, 310, 1628-1632. https://doi.org/10.1126/science.1111773

[8] Norris, K., Asase, A., Collen, B., Gockowksi, J., Mason, J., Phalan, B. and Wade, A. (2010) Biodiversity in a Forest-Agriculture Mosaic-The Changing Face of West African Rainforests. Biological Conservation, 143, 2341-2350. https://doi.org/10.1016/j.biocon.2009.12.032

[9] Bromhead, M. (2012) Forest, Trees and Woodlands in Africa: An Action Plan for World Bank Engagement. World Bank, Washington DC.

[10] Fraterrigo, J.M., Turner, M.G., Pearson, S.M. and Dixon, P. (2005) Effects of Past Land Use on Spatial Heterogeneity of Soil Nutrients in Southern Appalachian Forests. Ecological Monographs, 75, 215-230. https://doi.org/10.1890/03-0475

[11] Rhemtulla, J.M., Mladenoff, D.J. and Clayton, M.K. (2007) Regional Land-Cover Conversion in the U.S. Upper Midwest: Magnitude of Change and Limited Recovery in Wisconsin (1850-1935-1993). Landscape Ecology, 22, 57-75. https://doi.org/10.1007/s10980-007-9117-3

[12] Rhemtulla, J.M., Mladenoff, D.J. and Clayton, M.K. (2009) Legacies of Historical Land Use on Regional Forest Composition and Structure in Wisconsin, USA 
(Mid-1800s-1930s-2000s). Ecological Applications, 19, 1061-1078. https://doi.org/10.1890/08-1453.1

[13] Lambin, E.F. and Meyfroidt, P. (2011) Global Land Use Change, Economic Globalization and the Looming Land Scarcity. Proceedings of the National Academy of Sciences of the United States of America, 108, 3465-3472.

https://doi.org/10.1073/pnas.1100480108

[14] Turner, B.L., Lambin, E.F. and Reenberg, A. (2007) The Emergence of Land Change Science for Global Environmental Change and Sustainability. Proceedings of the National Academy of Sciences of the United States of America, 104, 20666-20671. https://doi.org/10.1073/pnas.0704119104

[15] Anderson, E. (1976) A Land Use and Land Cover Classification System for Use with Remote Sensor Data. Geological Survey Professional Paper, No.964. U.S. Government Printing Office, Washington DC, 28. https://doi.org/10.3133/pp964

[16] Sassen, M., Sheil, D., Giller, K.E. and Braak, C.J.F. (2012) Complex Contexts and Dynamic Drivers: Understanding Four Decades of Forest Loss and Recovery in an East African Protected Area. Biological Conservation, 159, 257-268. https://doi.org/10.1016/j.biocon.2012.12.003

[17] Enaruvbe, G.O. and Atafo, O.P. (2014) Analysis of Deforestation Pattern in the Niger Delta Region of Nigeria. Journal of Land Use Science, 11, 113-130. https://doi.org/10.1080/1747423X.2014.965279

[18] Igu, N.I. (2017) Swamp Forest Use and Loss in the Niger Delta: Contextual and Underlying Issues. Open Journal of Forestry, 7, 34-47.

https://doi.org/10.4236/ojf.2017.71003

[19] Tilman, D., Balzer, C., Hill, J. and Befort, B.L. (2011) Global Food Demand and the Sustainable Intensification of Agriculture. Proceedings of the National Academy of Sciences of the United States of America, 108, 20260-20264. https://doi.org/10.1073/pnas.1116437108

[20] Igu, N.I. and Marchant, R. (2017) Potentials and Determinants of Carbon Storage of Freshwater Swamp Forests in the Niger Delta. Open Journal of Ecology, 7, 199-210. https://doi.org/10.4236/oje.2017.73015

[21] Rembold, K., Mangopo, H., Tjitrosoedirdjoc, S. and Kreft, H. (2017) Plant Diversity, Forest Dependency, and Alien Plant Invasions in Tropical Agricultural Landscapes. Biological Conservation, 213, 234-242. https://doi.org/10.1016/j.biocon.2017.07.020 